\title{
Exclusion without trial? Exclusion of evidence and abbreviated procedures
}

\author{
Exclusão sem julgamento? llicitude probatória \\ e procedimentos abreviados
}

Thomas Weigend ${ }^{1}$

Universität zu Köln, Germany thomas.weigend@uni-koeln.de https://orcid.org/0000-0002-6862-0500

\begin{abstract}
Aвstract: Many legal systems have adopted rules that lead to the exclusion of evidence that has been obtained in violation of procedural rules. Exclusion normally occurs before the trial begins or even during trial. However, the majority of criminal cases are today not resolved through a full trial but by some kind of abbreviated procedure, e.g., through a guilty plea or a written penal order. In this article, the author claims that exclusionary rules should, by and large, also apply in such abbreviated proceedings. Practical obstacles could be overcome by a more active involvement of defense counsel in abbreviated proceedings.
\end{abstract}

KeYwords: abbreviated proceedings; exclusionary rule; guilty plea; penal order.

ResUMO: Muitos sistemas jurídicos adotaram normas que acarretam a exclusão de provas que tenham sido obtidas com violação a regras procedimentais. $A$ exclusão normalmente ocorre antes do início do processo ou mesmo durante o seu transcorrer. Contudo, a maioria dos casos criminais atualmente não são resolvidos por meio de um processo completo, mas por alguma espécie de procedimento abrevia, por exemplo, um acordo penal ou uma ordem penal em procedimento por decreto. Neste artigo, sustenta-se que as normas de exclusão probatória devem ser amplamente aplicadas em procedimentos abreviados.

1 Professor emeritus, University of Cologne, Germany. Dr. jur. (University of Freiburg, Germany). 
Obstáculos práticos podem ser superados por um envolvimento mais ativo da defesa técnica nos procedimentos abreviados.

Palavras-chave: procedimentos abreviados; ilicitude probatória; acordos penais; ordem penal por decreto.

\section{INTRODUCTION}

The exclusion of illegally obtained evidence means that the relevant information or items cannot be presented at the trial and the judgment must not be based on them. In recent decades, however, a full trial has in many jurisdictions become a statistically exceptional way of disposing of criminal cases. ${ }^{2}$ This fact raises the question whether exclusionary rules are relevant if a case is disposed of without trial. If a criminal case takes a "shortcut to justice", does inadmissibility of evidence still play a role?

In this article, I do not intend to deal with this question from the perspective of a single legal system but will attempt to elaborate on the general function of exclusionary rules in abbreviated procedures and will suggest possible solutions.

\section{Criminal Justice without Trial}

If a case goes to trial, it is normally the court that rules on the admissibility of evidence that may be subject to exclusion. Many legal systems have, however, implemented ways of sanctioning offenders without holding a full trial on the charges. There exists a broad array of such abbreviated proceedings in different jurisdictions. ${ }^{3}$ In some countries,

2 For example, in Germany only $10 \%$ of cases reported to the police with a known suspect are eventually brought to trial. Whereas $73 \%$ of the reported cases are dismissed for insignificance or lack of sufficient evidence, $16 \%$ are disposed of through abbreviated proceedings. See Thomas Weigend, No News is Good News: Criminal Sentencing in Germany since 2000, in: Michael Tonry (ed.), Sentencing Policies and Practice in Western Countries, pp. 83-106 (2016) at 92.

3 For an overview see Gwladys Gilliéron, Comparing Plea Bargaining and Abbreviated Trial Procedures, in: Darryl K. Brown, Jenia I. Turner and Bettina 
for example in England and the United States, ${ }^{4}$ the defendant's formal plea of guilty (often entered after negotiations with the prosecution) obviates the need for the taking of evidence in court. Other jurisdictions provide for the option of mini trials in which a judge takes cognizance of the results of the police investigation, any statement of the defendant, and possibly the testimony of individual witnesses and passes judgment on that basis. ${ }^{5}$ Another option is a written judgment issued by the judge based on a proposal of the prosecutor, which becomes final unless the defendant files an objection within a short period of time. ${ }^{6}$ Germany provides for the option of a "regular" trial in which the defendant's confession provides a shortcut to conviction and the imposition of a sentence that has been agreed upon previously. ${ }^{7}$ Some countries, like Brazil, prefer to permit formal conviction only on the basis of a trial but provide for informal sanctioning by way of conditional dismissal of prosecution. ${ }^{8}$

If any of such abbreviated proceedings are employed, the question arises whether illegally obtained evidence that would be subject to exclusion at trial may be taken into consideration for the disposition of the case.

\section{Two Case Scenarios}

Two case scenarios may demonstrate the problem:

Case 1 - Pillow talk: $\mathrm{S}$ is suspected of dealing with illegal drugs. Without the required judicial warrant, the police secretly install a hidden

Weißer (eds.), The Oxford Handbook of Criminal Process, 2019, pp. 703-727.

4 See Jenia I. Turner, Plea Bargaining Across Borders, pp. 7-72 (2009); Mary Vogel, Plea Bargaining under the Common Law, in: Darryl K. Brown, Jenia I. Turner and Bettina Weißer (eds.), The Oxford Handbook of Criminal Process, 2019, pp. 729-760.

5 See, e.g., Art. 438 et seq. Italian Code of Criminal Procedure (Giudizio abbreviato).

6 See, e.g., Arts. 495 - 495-6 French Code of Criminal Procedure (Ordonnance pénale).

7 See $§ 257 c$ German Code of Criminal Procedure (Verständigung).

8 Brazilian Lei 9.099/95 Art. 89 (suspensão condicional do processo); see also $\S 153$ a German Code of Criminal Procedure. 
microphone in S's bedroom and put all conversations on tape. Talking to his wife, $\mathrm{S}$ mentions that he received a shipment of cocaine and put it in the garage. Based on this taped conversation, the police break into S's garage the next day and confiscate a small amount of cocaine. $S$ is indicted for the illegal sale of controlled substances. He agrees to have his case resolved in an abbreviated proceeding operational in the relevant jurisdiction. In this procedure, the prosecution offers the evidence collected during the investigation to a single judge, who affords $\mathrm{S}$ the opportunity to be heard. S elects to remain silent, and the judge then proceeds directly to judgment, basing S's conviction and sentence on the cocaine found in his garage.

Case 2 - The burglar's confession: $\mathrm{S}$ is suspected of having committed a burglary. Police officer $P$ arrests him and interrogates him in the police station in the absence of a lawyer. When $\mathrm{S}$ denies his involvement in the burglary, P says that he and his colleagues have certain means to make him talk, implying physical violence. $S$ thereupon confesses to the crime. The prosecutor files an indictment, charging $\mathrm{S}$ with armed burglary. Shortly before trial, S's defense lawyer D approaches the prosecutor and asks for a "deal". The prosecutor mentions that $S$ had already confessed to the crime at the police station and therefore declines to reduce the charge; but she offers not to oppose the lawyer's request for a lenient sentence if $\mathrm{S}$ accepts his responsibility in court. In a judicial hearing, $\mathrm{S}$ formally admits his guilt. Based on the admission of guilt, $\mathrm{S}$ is convicted of armed burglary and receives a lengthy prison sentence.

It may be assumed that the key evidence (the cocaine in Case 1 and the confession in Case 2) would be inadmissible at a trial because of serious violations of S's procedural rights. ${ }^{9}$ But does the fact that the evidence was obtained illegally also invalidate the convictions of $S$ in the special procedures used? In addressing this question, I will first briefly recall the rationales for the exclusion of illegally obtained evidence. In a second step, I will ask whether these rationales apply to abbreviated procedures and to dispositions without trial. Since the answer will - with

9 Since the cocaine in Case 1 is evidence only derived from the illegal taping of the conversation between $\mathrm{S}$ and his wife, not every jurisdiction may provide for automatic exclusion. However, given the blatant violation of S's privacy it may be safe to assume that most judges would exclude the cocaine from the trial. 
some qualifications - be in the affirmative, the final step of this article will be to look for impediments to exclusion of evidence in abbreviated procedures and for ways to overcome these obstacles.

\section{Rationales for Excluding Evidence}

A vast amount of literature has dealt with the rationale of the "exclusionary rule". ${ }^{10}$ The starting point for the relevant considerations is the fact that "excluding" evidence reduces the factual basis of the court's judgment and thus interferes with the court's mission of finding the "truth" and basing the judgment on that finding. ${ }^{11}$ Excluding relevant evidence with probative value creates an obstacle to truth-finding and must therefore be regarded as an exception, especially since exclusion is often based on extra-procedural interests. ${ }^{12}$

10 See, e.g., Guido Calabresi, The Exclusionary Rule, 26 Harvard Journal of Law and Public Policy 111-118 (2003); Kai Ambos, Beweisverwertungsverbote, 2010; Stephen C. Thaman (ed.) Exclusionary Rules in Comparative Law (2013); Jenia I. Turner, The Exclusionary Rule as a Symbol of the Rule of Law, 67 SMU Law Review 821-833 (2014); Christopher Slobogin, A Comparative Perspective on the Exclusonary Rule in Search and Seizure Cases, in: Jacqueline Ross and Stephen Thaman (eds.), Comparative Criminal Procedure (2016), pp. 280-308; Jenia I. Turner, Limits on the Search for Truth in Criminal Procedure: A Comparative View, ibid., pp. 35-73; Sabine Gless and Thomas Richter (eds.), Do Exclusionary Rules Ensure a Fair Trial?, 2019; Shawn Boyne, Truth or Justice: A Comparative Look at the Exclusionary Rule in Germany and the United States, in: Arnd Sinn et al. (eds.), Populismus und alternative Fakten - (Straf-)Rechtswissenschaft in der Krise? (2020), pp. 19-46.

11 See Stephen C. Thaman, Balancing Truth against Human Rights, in: Stephen C. Thaman (ed.), Exclusionary Rules in Comparative Law, 2013, pp. 403-446; Jenia I. Turner, Regulating Interrogations and Excluding Confessions in the United States, in: Sabine Gless and Thomas Richter (eds.), Do Exclusionary Rules Ensure a Fair Trial? Springer Open 2019, p. 93 at 104-107 (citing examples of "balancing" from United States case law).

12 See German Federal Constitutional Court, Judgment of 7 Dec. 2011, 2 BvR 2500/09, 2 BvR 1857/10, 130 Entscheidungen des Bundesverfassungsgerichts 1, marginal notes 111-115; German Federal Court of Justice, Judgment of 13 Jan. 2011, 3 StR 332/10, 56 Entscheidungen des Bundesgerichtshofes in Strafsachen 127 at 132. 
Three main rationales have been suggested to justify the exclusion of evidence:

(1) Deterrence of police misconduct

(2) Protection / vindication of suspects' procedural rights

(3) Maintaining the integrity of court proceedings. ${ }^{13}$

The first two of these considerations look backward to the violation of legal rules that has occurred and aim at providing some kind of compensation. The police officer is "punished" for his fault by being told that the illegally obtained evidence is ignored by the court and - in the extreme case - that the defendant is acquitted for lack of sufficient other evidence. At the same time, the police officer and his colleagues are expected to realize that a violation of procedural rules "doesn't pay" and that it is better to act lawfully in the future. ${ }^{14}$ With regard to the defendant, in most cases the violation of his rights (the right to privacy in Case 1 and the privilege against forced self-incrimination in Case 2) cannot be undone. But the exclusion of evidence may give him a double (immaterial) compensation. The decision to exclude the results of the illegal act from the evidence implies a judicial finding that his rights were violated; and at the same time exclusion reduces the risk that he is convicted. ${ }^{15}$

Both of these rationales generally provide a legitimate basis for excluding evidence, but the consequences may appear excessive if the violation of procedural law was not grievous and if the exclusion of the

13 For a comparative overview of the use and problems of these rationales see Jenia I. Turner and Thomas Weigend, The Purposes and Functions of Exclusionary Rules, in: Sabine Gless and Thomas Richter (eds.), Do Exclusionary Rules Ensure a Fair Trial? pp. 255-282 (2019). A brief comparative account of rationales for the exclusion of evidence can also be found in Yukun Zong, Beweisverwertungsverbote im Strafverfahren, 2018, pp. 447-458.

14 See Yvonne Marie Daly, Judicial Oversight of Policing: Investigations, Evidence and the Exclusionary Rule, 55 Crime, Law and Social Change 199-215 (2011); referring to Swiss law see Sabine Gless and Jeannine Martin, Water Always Finds Its Way, in: Michele Caianiello and Jaqueline S. Hodgson (eds.), Discretionary Criminal Justice in a Comparative Context, 2015, 159-184 at 171.

15 For a more thorough analysis see Andrew Ashworth, Excluding Evidence as Protecting Rights, 3 Criminal Law Review 723-735 (1977). 
particular piece of evidence means that the defendant will have to be acquitted in a case of serious crime. In addition, it is not self-understood that exclusion of evidence will indeed have a positive impact on future police conduct. Any positive effect depends on several conditions, e.g., whether the police officer in question learns of the exclusion and whether he cares about the outcome of the trial after the case has been "cleared" for the purposes of the police. ${ }^{16}$ This potential excessiveness explains the rule in some jurisdictions that exclusion of illegally obtained evidence is not automatic but should depend on a balancing of the interests of the individual that was wronged against the interests of law enforcement. Exclusion will then be ordered only if it is more important, in the individual case, to vindicate the defendant's procedural rights and to deter the police from repeating the fault than to convict the defendant of the crime charged. ${ }^{17}$ On the other hand, permitting the court to perform this balancing operation introduces an element of vagueness and unpredictability into the process. This also reduces the deterrent effect, because the police may be encouraged to employ illicit methods and hope for a "favorable" outcome of the balancing process and the eventual admission of the incriminating evidence.

16 For a seminal analysis see Randy E. Barnett, Resolving the Dilemma of the Exclusionary Rule, 32 Emory Law Journal 937 at 947-959 (1983). For further discussion see Christopher Slobogin, Why Liberals Should Chuck the Exclusionary Rule, 1999 University of Illinois Law Review 363-446; Drury D. Stevenson, Entrapment and the Problem of Deterring Police Misconduct, 37 Connecticut Law Review 67 at 77-79 (2004); Kit Kinports, Culpability, Deterrence, and the Exclusionary Rule, 21 William and Mary Bill of Rights Journal 821-856 (2013). For empirical findings on deterring police misconduct see Christopher J. Harris and Robert E. Worden, The Effect of Sanctions on Police Misconduct, 60 Crime \& Delinquency 1258-1288 (2014).

17 For Germany, see Federal Constitutional Court, Decision of 13 May 2015, 2 BvR 616/13, marginal notes 41, 42; Federal Court of Justice, Judgment of 21 Feb. 1964, 4 StR 519/63, 19 Entscheidungen des Bundesgerichtshofes in Strafsachen 325; Lutz Meyer-Goßner and Bertram Schmitt, Strafprozessordnung, $63^{\text {rd }}$ ed. 2020, Einleitung marginal note 55a. For Austria, see $\S 166$ subsec. 1 no. 2 Code of Criminal Procedure (illegally obtained statements of the accused or of a witness must not be used as evidence "if exclusion is indispensable for compensating for the violation"). But see Art. 171 $\S 6$ Polish Code of Criminal Procedure (absolutely excluding statements of the accused or of a witness made under conditions precluding the possibility of free expression). 
But what, then, about the third rationale, i.e., maintaining the integrity of court proceedings? ${ }^{18}$ This aspect does not aim at making up for past faults but focuses on the present trial. Assume that there is a written confession in Case 2 and that there are blood stains on the document as a result of a severe beating of the defendant by the interrogating officer. Wouldn't it run counter to the concept of a court of law to use this confession as evidence? The same notion may apply in the Case 1 situation: Will a court of law be willing to use evidence that was obtained through illegally eavesdropping on the defendant's bedroom conversation with his wife? This rationale for excluding evidence has the advantage of not being based on extra-procedural concerns; it promotes the intrinsic goal of conducting a fair process. It must be conceded, however, that the "integrity of the court" approach, like the proportionality balancing mentioned above, does not have clear contours. It is theoretically conceivable to claim that any procedural fault so taints the ensuing evidence that a court should not use it. But that argument is difficult to maintain if the fault was technical and unintentional, for example, a search based on a judicial warrant the temporal validity of which had just expired. Thus, if the seriousness of the procedural fault determines the admissibility of evidence under this rationale, a normative judgment is necessary and a measure of uncertainty again enters the legal analysis.

Summing up, it appears that exclusionary rules are undergirded by a number of concurring rationales. They have in common that they provide a strong basis for excluding evidence obtained by means of serious violations of important procedural rights. They leave open, however, a gray area of minor or merely technical violations of procedural rules, where exclusion of important evidence may not be warranted under all circumstances, especially if the piece of evidence in question is crucial for the determination of the truth.

18 For analysis of this rationale see Robert M. Bloom and David H. Fentin, 'A More Majestic Conception', 13 University of Pennsylvania Journal of Constitutional law 47-80 (2010); Jenia I. Turner, The Exclusionary Rule as a Symbol of the Rule of Law, 67 SMU Law Review 821-833 (2014); Hock Lai Ho, The Fair Trial Rationale for Excluding Wrongfully Obtained Evidence, in: Sabine Gless and Thomas Richter (eds.), Do Exclusionary Rules Ensure a Fair Trial? pp. 283-305 (2019). See also the practitioner's perspective on this issue by Susanne Knickmeier, ibid. pp. 329-347. 


\section{Abbreviated Forms of Disposing of Criminal Cases}

\section{General Applicability of Exclusionary Rules}

Let us now turn to the question of whether exclusionary rules may or should be applied in abbreviated proceedings. If we consider the various rationales of exclusionary rules, it appears obvious that there exists no persuasive reason for limiting their applicability to cases in which a full trial takes place. Any such limitation would diminish the incentive for police to abide by procedural law, because they could hope that the evidence obtained illegally could lead to the conviction of the suspect in an abbreviated proceeding. There would be no vindication or compensation for the violation of the suspect's rights. And if a sanction is imposed on the suspect in a criminal process, the officials involved in that proceeding would have to take into account the tainted piece of evidence, thereby putting into doubt the legitimacy and integrity of the process. If the rationales of the exclusionary rule apply to abbreviated proceedings, so should the exclusionary rule itself. In fact, any evidence that is inadmissible at trial should be instantly removed from the process. Ideally, such evidence would not only be inadmissible in any court proceeding but prosecutors should also disregard it when deciding on whether to file an indictment.

By extending a strict exclusionary rule to abbreviated proceedings, however, the problem of reducing the factual basis of the decision is transferred to these proceedings. In other words, the (remaining) truthorientation of abbreviated criminal procedures is damaged inasmuch as relevant evidence is removed from the consideration of the decisionmaker. To reduce this problem, the arguments in favor of exclusion of tainted evidence should be weighed against the interest in basing the decision on an approximation to the "real" facts of the case. This leads to a further complication, however: A proper balancing of interests can take place only at the trial stage, when all facts about the violation have been disclosed and it has become clear to what extent the evidence in question is needed for arriving at a fair disposition of the case. Yet, the prosecutor must make her decision on a provisional factual basis and without the benefit of argument from the defense. Under these circumstances, it is 
not unethical for a prosecutor to rely on evidence of doubtful legality and present it in court, waiting to see whether the defense objects and what the judge's ruling may be.

\section{Different Types of Abbreviated Proceedings}

For assessing the operation of the exclusionary rule in abbreviated proceedings, it is useful to take a closer look at the existing variants of such proceedings, which all have in common that a sanction is imposed on the offender without a complete presentation of all relevant evidence in a public trial. ${ }^{19}$ Given the vast array of different criminal proceedings without a full trial, there is no point in making general statements about "the" abbreviated criminal process. Yet, we can distinguish three basic types of abbreviated proceedings:

\section{(a) Prosecutorial sanctioning}

Forms of prosecutorial sanctioning can be found in many legal systems. Although prosecutors normally cannot make formal findings of guilt and cannot impose criminal punishment, they dispose of tools such as deferred prosecution, conditional dismissal of charges, informal probation, and so-called transactions. ${ }^{20}$ They all have in common that a sanction of some kind (a fine, a compensation payment to the victim, or a probation-type set of obligations) is imposed on a suspect with his consent; if the obligation is fulfilled, there will be no formal prosecution and trial. The obligation imposed on the suspect can only be interpreted

19 On the worldwide spread of abbreviated procedures see Máximo Langer, From Legal Transplants to Legal Translations: The Globalization of Plea Bargaining and the Americanization Thesis in Criminal Procedure, 45 Harvard International Law Journal (2004), pp. 1-62.

20 See, e.g., Art. 216bis Belgian Code of Criminal Procedure ("transaction" between prosecutor and suspect over payment of money for dismissal of prosecution); Brazilian Lei 9.099/95 Art. 89 (suspensão condicional do processo); Art. 167 sec. 2 Dutch Code of Criminal Procedure; § 153a German Code of Criminal Procedure (conditional dismissal of prosecution); Art. 342 Polish Code of Criminal Procedure (conditional discontinuance of prosecution). 
as a response to the offense he is alleged to have committed although his guilt has not been proved in court. In this type of proceeding, there is no presentation of evidence and no formal hearing. Still the question remains to what extent the prosecutor needs a factual basis for her decision and how that factual basis can be created. ${ }^{21}$

\section{(B) Formal Acceptance of Guilt}

The second type of abbreviated proceedings can be exemplified by the "guilty plea" typical of the Anglo-American criminal process. ${ }^{22}$ In accordance with a long common law tradition, the defendant at the beginning of the judicial process is asked to declare whether he is guilty or not guilty. If his plea is "guilty" and if the judge accepts the plea after a summary examination of its voluntariness and its "factual basis", ${ }^{23}$ no evidence concerning the defendant's guilt will be presented in court; his formal declaration is regarded as a sufficient basis for the court's finding of guilt. The court will then proceed directly to sentencing the defendant. The defendant's plea of guilty is often preceded by negotiations between the prosecutor and the defense lawyer. The prosecutor will usually offer some incentive for the defendant to plead guilty, such as a reduction of the original charges or a recommendation for a lenient sentence. On the

21 In Germany, commentators demand only suspicion sufficient for filing an indictment; Herbert Diemer, in: Rolf Hannich (ed.), Karlsruher Kommentar zur Strafprozessordnung, $8^{\text {th }}$ ed. 2019, § 153a marginal note 11; Lutz Meyer-Goßner and Bertram Schmitt, Strafprozessordnung, $63^{\text {rd }}$ ed. 2020, § 153a marginal note 7 .

22 For overviews see Jacqueline Ross, The Entrenched Position of Plea Bargaining in United States Legal Practice, 54 American Journal of Comparative Law 717-732 (2006); Jenia I. Turner, Plea Bargaining across Borders, 2009, pp. 7-72 (U.S.); Stephen Thaman, World Plea Bargaining (2010); Marc L. Miller, Ronald F. Wright, Jenia I. Turner, and Kay Levine, Criminal Procedures: Prosecution and Adjudication, $6^{\text {th }}$ ed. 2019, pp. 309-396.

23 In the United States, the "factual basis" is normally "examined" perfunctorily, and in some States judges rely on a mere written declaration that such a basis exists. See Tina M. Zottoli et al., State of the States: A Survey of Statutory Law, Regulations and Court Rules Pertaining to Guilty Pleas Across the United States, 37 Behavioral Sciences and the Law 388-434 (2019). 
other hand, the prosecutor may point out that a very severe sentence might be imposed if the defendant goes to trial and is found guilty.

In other legal systems, where the notion of "pleading guilty" has not been established, a functional equivalent is a joint motion of the prosecutor and the defendant to the judge for the imposition of an agreed-upon sentence. ${ }^{24}$ The judge is typically free to accept or reject the proposal. In the latter case, a trial will be held unless another disposition can be found. As in the guilty plea system of the common law jurisdictions, no evidence is taken in court, but the acceptance of the sanction by the defendant is seen as a sufficient legitimization of the proposed disposition. ${ }^{25}$

\section{(c) Penal Orders and Mini Trials}

The common denominator of the third type of abbreviated proceedings is the fact that the defendant's conviction is based on the results of the pretrial investigation. This kind of disposition can take several forms. One common sub-type is the so-called penal order ${ }^{26}$ : The prosecutor drafts a judgment including a sentence based on the police file of the investigation. The draft order is then forwarded to a single judge, who can sign or reject it. ${ }^{27}$ If the judge approves and signs the order, it

24 See, e.g., Arts. 495-7 - 495-16 French Code of Criminal Procedure (comparution sur reconnaissance préalable de culpabilité); Art. 335 Polish Code of Criminal Procedure.

In other jurisdictions, negotiated dispositions are limited to cases in which the defendant is willing to provide incriminating evidence on other offenders; see Brazilian Law 12.850/2013. Although the vocabulary of "guilty plea" is used in this connection, the dismissal or reduction of charges here is not tied to an acceptance of responsibility but to aiding in the prosecution of other suspects.

26 See, e.g., Arts. 495 - 495-6 French Code of Criminal Procedure (ordonnance pénale); §§ 407-412 German Code of Criminal Procedure (Strafbefehl).

27 In the Netherlands, the prosecutor himself issues the penal order; the defendant can however file an objection and thereby have the case transferred to the District Court for trial. Penal orders cannot include a prison sentence (Arts. 257a et seq. Dutch Code of Criminal Procedure). For similar proceedings (prosecutorial penalty writ) in Norway see Sections 255 et seq. Norwegian Criminal Procedure Act. On the practice of penal orders and its 
becomes final and acquires the effect of a regular court judgment unless the defendant files an objection or appeal in due course. In case of an objection, the matter is set for trial in court. The penal order's main field of application is minor offenses, for example, small theft and traffic violations. The sentence to be imposed by penal order is typically limited to non-custodial sanctions (including conditional prison sentences).

Another sub-type is a summary trial before a judge with only a minimum of evidence-taking, or with none at all. For example, in Italy the judge can, with the defendant's consent, proceed to a giudizio abbreviato. ${ }^{28}$ In that proceeding, the judgment can be based on the file of the prosecutorial investigation, but the judge may also interrogate individual witnesses if she deems that necessary for coming to a firm conclusion about the defendant's guilt or innocence. ${ }^{29}$ In the Norwegian abbreviated trial, the judge holds a hearing with only the defendant present and passes sentence immediately after the defendant has confessed to the facts named in the indictment. ${ }^{30}$ In either case, the incentive for the defendant to submit to the abbreviated disposition of the case is a sentence reduction. ${ }^{31}$

Germany has a similar type of disposition which is, however, dressed up as a formal trial. ${ }^{32}$ In the Verständigung procedure, the defense lawyer and the judge(s) of the trial court conduct negotiations before the

problems see Marc Blotwijk and Michael Fernandez-Bertier, Out-of-Court Criminal Dispute Resolution in the Netherlands, Belgium and the U.S., Tijdschrift voor Sanctierecht \& Onderneming 2015, 95-107 at 98.

Arts. 438 et seq. Italian Code of Criminal Procedure.

29 Art. 441 subsec. 5 Italian Code of Criminal Procedure. The defendant may also propose evidence to be taken; Art. 441bis subsec. 5 Italian Code of Criminal Procedure.

30 Art. 248 Norwegian Criminal Procedure Act.

31 See Art. 442 subsec. 2 Italian Code of Criminal Procedure (sentence for petty offenses is reduced by half, sentence for other offenses is reduced by one third).

32 For a comparison of the German Verständigung procedure with guilty plea proceedings in England and the United States see Jenia I. Turner and Thomas Weigend, Negotiated Case Dispositions in Germany, England, and the United States, in: Kai Ambos, Antony Duff, Julian Roberts and Thomas Weigend (eds.), Core Concepts in Criminal Law and Criminal Justice, vol. I, Cambridge 2020, pp. 389-427. 
beginning of (or sometimes during) the trial. The judge, who is familiar with the file of the pretrial investigation, makes a "predictive" offer of imposing a sentence within a certain range if the defendant comes forward with a confession at the trial. ${ }^{33}$ If both sides agree and the prosecutor does not veto the deal, the court is bound by the offer. ${ }^{34}$ The trial then begins with the defendant making the confession as agreed, and the court may (but often does not) take additional evidence. ${ }^{35}$ If everything goes according to plan, the defendant then receives the agreed-upon sentence and the case is closed. ${ }^{36}$

The feature that differentiates this type of a "shortcut to justice" from the guilty plea is the fact that the defendant's consent is not the sole legitimating basis for a finding of guilt. The court relies on the file containing the results of the pretrial investigation, ${ }^{37}$ on the defendant's confession, on additional witness testimony, or on a combination of all three. In any event, there is supposed to exist a sufficiently reliable factual basis for the judgment even though no regular trial has been held.

\section{The Role of Exclusion of Evidence in Abbreviated Proceedings}

Having obtained an overview of various types of sanctioning options without a full trial, we may return to the question of whether exclusionary rules should play a role in such proceedings. We can again distinguish among the three types of abbreviated procedures as defined above.

$33 \S 257$ c subsec. 3 German Code of Criminal Procedure.

$34 \S 257$ c subsec. 3 sent. 4 German Code of Criminal Procedure.

$35 \S 257 c$ subsec. 1 sent. 2 German Code of Criminal Procedure obliges the court to introduce all evidence that can be relevant for its decision. In practice, however, courts often regard the defendant's confession as a sufficient basis of the judgment.

36 For a recent empirical study on the practice of Verständigung see Karsten Altenhain, Matthias Jahn, Jörg Kinzig, Die Praxis der Verständigung im Strafprozess, 2020.

37 The court must not base the judgment directly on the file of the pretrial investigation. But the professional judges will have read the file before the start of the trial and obtain from it a certain preconception of the facts of the case. 


\section{Prosecutorial Sentencing}

With regard to prosecutorial sanctioning, we can start from the rule (developed above) that the prosecutor should not base her decisions on evidence that would not be admissible in court. Consequently, proposals for conditional dismissal or pretrial probation and similar sanctioning mechanisms should be made only if the prosecutor can reasonably expect to obtain a conviction at trial based on admissible evidence. If the evidence, minus those items that are likely to be excluded, is not sufficient to prove the defendant's guilt beyond a reasonable doubt, it would be oppressive to propose to the suspect to fulfill certain obligations (such as paying a fine) although he would probably be acquitted if the prosecutor brought the case to trial. So, in the example Case 2, if the prosecutor does not have much evidence for the defendant's involvement in the burglary beyond the inadmissible confession, it would be unethical for her to make the defendant an offer to dismiss his case if he made a payment or provided several hours of unpaid work in a public interest project. It is conceivable that the defendant might still accept the offered disposition in order to get rid of the threat of prosecution or because he wishes to atone for a moral wrong he committed; but the prosecutor should at least candidly tell the defendant that there is a low likelihood that he would be convicted at trial.

As mentioned above, however, the prosecutor has some leeway if the admissibility of illegally obtained evidence is dependent on a balancing of the seriousness of the procedural violation against the interest in truth-finding in the criminal process. Since this balancing must in the last resort be undertaken by the court based on the totality of the circumstances, the prosecutor may act on a reasonable possibility that the evidence will eventually be admitted. She may therefore make the suspect an offer for, e.g., deferred prosecution or conditional dismissal even though she cannot be certain that some illegally obtained evidence would be admitted by the trial court.

\section{Formal Acceptance of Guilt}

If the defendant enters a guilty plea or accepts a finding of guilt without prior evidence-taking, his declaration, as we have seen, 
is regarded as a sufficient basis for conviction. Since no evidence is presented to the court, exclusionary rules logically do not have a direct effect on the proceedings following the guilty plea. But does that mean that grave procedural violations that occurred in the investigation phase become irrelevant if the defendant accepts the prosecutor's offer to plead guilty to a reduced charge or in exchange for a recommendation of a lenient sentence? It is not quite so simple. First, as we have seen above, the prosecutor should not base her charging decision on clearly inadmissible evidence. That rule also extends to decisions concerning the plea bargaining process. Consequently, the prosecutor should be ethically precluded from offering the defendant a plea deal if she knows that evidence critical to the prosecution case would be excluded if the case went to trial. ${ }^{38}$ In practice, however, if the prosecutor knows that something "went wrong" during the investigation and that key evidence may be (or: definitely is) inadmissible, she may indeed offer the defendant a particularly attractive deal so as not to lose the case altogether.

That is a problem of prosecutorial ethics, but it may also lead to a legal issue: Can one say that a guilty plea is voluntary if the defendant wrongly assumes that the prosecution has admissible evidence sufficient to prove his guilt, while in fact key evidence is inadmissible? Take Case 2 as an example again: If the defendant mistakenly thinks that his forced confession at the police station can be used against him at the trial and that he therefore does not have the slightest chance of being acquitted, and then pleads guilty - is that plea voluntary? One could argue that the defendant was not forced to plead guilty and that it was his free decision to waive the chance of an acquittal and to acknowledge his guilt. But doesn't voluntariness presuppose having the information necessary to make an intelligent decision? One would probably not hesitate to invalidate a plea if the prosecutor had intentionally misled the defendant about the availability of incriminating evidence. But in some jurisdictions the defense is asked to plead without being given full access to relevant information. The prosecutor may have to disclose evidence that could be used by the defense in its favor at trial, but he need not grant the defense

38 See Russell Gold, Beyond the Judicial Fourth Amendment: The Prosecutor's Role, 47 UC Davis Law Review 1591-1665 (2014). 
lawyer discovery of incriminating evidence. ${ }^{39}$ If the prosecutor's bag of evidence contains mainly inadmissible items, would it count as deception to even make a plea offer to the defense?

The answers to that question may well differ, depending on each jurisdiction's rules on the information that must be available to the defendant before he decides on the plea. But as a general rule, the defense should not be forced to plead "blind"; and in particular the defendant should be alerted to facts that might jeopardize the admissibility of prosecution evidence. Only if the defense lawyer is aware of the relevant facts concerning (potential) inadmissibility and still - based on his own assessment of these facts - advises his client to plead guilty, this may be regarded as a legitimate tactical choice and should be respected as a voluntary plea. ${ }^{40}$

One may have doubts, however, whether there can ever be a valid acceptance of the use of a forced confession as evidence. German law provides that a statement resulting from threats, force, deceit, or other prohibited means is inadmissible even if the defendant later consents to its use at trial. ${ }^{41}$ But even that strict standard only rules out the admission of such evidence at trial and does not prevent the defendant, after proper information about the inadmissibility of the prior statement, ${ }^{42}$ from making another confession to the same facts. Nor does the ban on using a forced confession stand in the way of the defendant acknowledging guilt, for which he may have independent reasons.

39 See, for the United States, the 2002 U.S. Supreme Court decision in U.S. v. Ruiz, 536 U.S. 622 at 623 ("The Constitution does not require the Government to disclose material impeachment evidence prior to entering a plea agreement with a criminal defendant.”). See further Jenia I. Turner, Plea Bargaining Across Borders, pp. 40-41 (2009).

40 There are strong arguments in favor of involving a judge in the plea negotiation process; he could, among other things, make sure that crucial information is not withheld from the defense lawyer. See on this issue Jenia I. Turner, Judicial Participation in Plea Negotiation: A Comparative View, 54 American Journal of Comparative Law 501-570 (2006).

$41 \S 136$ a sec. 3 German Code of Criminal Procedure.

42 On this requirement, see European Court of Human Rights, Gäfgen v. Germany, case no. 22978/05, Judgment of 1 June 2010, $§ 182$. 


\section{Penal Orders and Mini Trials}

Finally, the question arises whether exclusionary rules have an impact on the various forms of abbreviated trials. To the extent that the judge actually takes evidence before making a decision, it is obvious that she must not use tainted evidence that would not be admissible at a full trial of the matter. But what about the proceeding in which the judge bases the decision only on the written record of the pretrial investigation? In that instance, taking judicial cognizance of the file of the investigation replaces the taking of evidence. The judge must consequently check the file to see whether certain evidence has been obtained illegally and would therefore be subject to exclusion. If that is the case, the judge must not base the decision on this evidence; she may consequently convict the defendant only if the remaining evidence apparent from the file is sufficient to establish his guilt beyond a reasonable doubt.

But perhaps the judge's use of evidence that would be inadmissible at a full trial might be legitimized by the defendant's advance consent? In most jurisdictions, an abbreviated procedure is available only with the defendant's consent. That consent does not refer to a finding of guilt (as in the guilty plea proceeding) but only to the judge's authority to dispense with taking evidence and to rely instead on the information contained in the police file. But does the defendant's consent then imply that the judge should be permitted to use any information she can find in the file, including illegally obtained evidence, or only such information as could also be introduced at trial? As a rule, the defendant's consent should be interpreted as extending only to the results of an investigation conducted in accordance with applicable legal rules. Returning to example Case 2, the defendant's declaration that the judge may issue a judgment based on the police file cannot be understood to extend to the confession extorted from him by the threat of force. ${ }^{43}$ This may be different only if the defendant and his lawyer were explicitly informed that the file contains evidence

${ }_{43}$ But see Art. 438 subsec. 6-bis Italian Code of Criminal Procedure, providing that the defendant's request to conduct an abbreviated proceeding implies the waiver of certain rules of exclusion of evidence (nullità) except instances of "absolute" invalidity of the evidence. 
that is likely to be inadmissible and have nevertheless given consent to the use of that evidence. ${ }^{44}$

The same standard should apply in the "penal order" type of proceeding. Although the prosecutor pre-formulates the judgment, the judge must not authorize it unless it is supported by the results of the investigation as documented in the file. This means that the judge is expected to read the file and examine what admissible evidence would be available at a trial. Only if, based on a summary evaluation, this evidence would be sufficient to support a finding of guilt may the judge issue the penal order. Even in this most abbreviated proceeding, then, the exclusion of evidence plays an important role: It removes illegally obtained evidence from the file on which the judge must base her decision on whether to issue the penal order as requested by the prosecutor.

As with prosecutorial decisions, however, the virtual exclusion of evidence from the file is limited to clear cases. The judge has more leeway if the facts as they appear from the file are such that they require a balancing of conflicting interests before a decision on exclusion can be made. In that situation, the judge should conduct a provisional balancing based on the limited information available at the time, which may lead to acceptance of some evidence that might eventually be excluded after full argument at a trial.

In conclusion, it can be said that a judgment in an abbreviated proceeding (including a penal order) must in the normal course of events not be based on evidence that would be inadmissible at a regular trial.

\section{Practical Problems}

Although these rules appear convincing in theory, there are obvious impediments to their application in practice. With regard to prosecutorial sanctioning (VI. 1. supra), the main problem lies in the lack of any exterior control on the prosecutor's decision-making. The question whether the prosecutor takes the (possible) inadmissibility

44 The defendant may be given an incentive to agree by a promise of an exceptionally lenient sentence. 
of evidence into account is entirely left to her conscientious review of the evidence and her readiness to dismiss a case without any sanction where the admissible evidence would not be strong enough to support a conviction. In theory, the defendant can obtain a judicial decision by rejecting an offer of, e.g., a conditional dismissal, but he will hardly be in a position at this stage to assess the strength of the (admissible) evidence against him and will therefore often not dare to refuse an offer of disposing of his case without a finding of guilt.

With regard to abbreviated dispositions with a finding of guilt (such as penal orders), the most serious problem is the frequent lack of an active defense at this stage of the proceedings. Penal orders, for example, are mostly used in trivial non-serious cases in which the court does not appoint a lawyer for the defendant. ${ }^{45}$ And even if there is an abbreviated trial with a hearing before a judge, a defense lawyer may not necessarily take the trouble of studying the prosecution file (if it is available to her at all) but will concentrate on obtaining a lenient sentence for her client. The defense lawyer as the driving force in any argument against the admissibility of evidence will hence normally not be present or at least will not invest much energy in arguing these matters unless she expects the case to go to a full trial. ${ }^{46}$

A further factor working against exclusion of evidence attaining practical relevance is inertia. The abbreviated forms of disposing of criminal cases have been invented for the very purpose of saving judges the effort and time needed for thoroughly reviewing the evidence. Judges will often unquestioningly rely on the police and the prosecution to have conducted a diligent investigation and to have abided by the law in doing so. Unless there are evident violations, or the judge has been alerted to potential evidence problems by the defense lawyer, the judge will assume that the investigation was conducted in accordance with the law and will

45 For example, in Germany a lawyer must be appointed for the defendant only if a (suspended) prison sentence is to be imposed; $§ 407$ subsec. 1, sent. 2 German Code of Criminal Procedure.

46 In the U.S., the chance of a successful defense motion to suppress some illegally obtained evidence may be a "bargaining chip" for the defense, leading to conviction with a reduced sentence. Cf. Slobogin (note 16, supra), at 375. 
accept the information contained in the file as a basis for his judgment. ${ }^{47}$ Typically, in an abbreviated process there is no room for an adversarial discussion of issues of evidence law.

\section{Possible Solutions}

What, then can be done to overcome the obstacles to arriving at a decision independently of inadmissible evidence? Two main approaches come to mind.

First, defense counsel should actively participate in abbreviated proceedings. One of the lawyer's functions is to familiarize herself with the information on the case and to alert the judge to possible evidence problems. Yet, although that demand is in line with an ideal system of criminal justice, it is not realistic to expect a lawyer to be appointed in every case, given the large number of petty cases processed in written form.

It will thus mostly remain for the prosecutor or the judge to conscientiously check the materials at his disposal for possible procedural faults that may make evidence inadmissible. If such problems appear from the file, he must decide whether the remaining evidence is strong enough to carry a conviction. If the case has reached the stage of judicial decisionmaking, there will be instances of doubt in which the judge cannot tell, from only reading the file, whether a procedural fault has occurred and whether it is serious enough to demand exclusion of the ensuing evidence. In this situation, the judge should either - where that is permissible - try to resolve that doubt by hearing individual witnesses who can clarify the matter or decline to decide the case in an abbreviated proceeding and instead set the case for trial. These obligations will undoubtedly make abbreviated dispositions a bit less attractive to practitioners. But since the judgment is issued in the judge's name, he can well be expected to make sure that there is sufficient admissible evidence available to convict the defendant before he finds him guilty.

47 For criticism of the German „penal order” proceeding along these lines see Felix Bommer et al., Alternativ-Entwurf Abgekürzte Strafverfahren im Rechtsstaat, 166 Goltdammer's Archiv für Strafrecht (2019) 1-128 at 84-85. 


\section{Conclusion}

The fact that evidence has been obtained illegally and therefore cannot be used at a trial has repercussions on the resolution of the case in informal criminal proceedings.

First, prosecutors should not rely on inadmissible evidence when offering the suspect an informal disposition, for example, a dismissal of the case without a formal charge in exchange for the defendant making a payment.

Second, a plea of guilty or a similar procedural declaration must be deemed involuntary and void if the defendant made it because he was misled about the admissibility of crucial incriminating evidence at the trial.

Third, a judge in an abbreviated proceeding that leads to a finding of guilt must not base his decision on evidence that would not be admissible at a trial. Because defendants cannot normally themselves assess the admissibility of evidence, and since criminal justice officials may tend to seek a consensual shortcut to judgment without a thorough examination of the evidentiary situation, defense counsel should get involved, whenever possible, in checking the hypothetical admissibility of evidence and alerting prosecutors and judges to possible problems.

\section{Select Bibliography}

ALTENHAIN, Karsten, JAHN, Matthias, and KINZIG, Jörg: Die Praxis der Verständigung im Strafprozess (2020).

AMBOS, Kai: Beweisverwertungsverbote (2010).

ASHWORTH, Andrew: Excluding Evidence as Protecting Rights, 3 Criminal Law Review 723-735 (1977).

BARNETT, Randy E.: Resolving the Dilemma of the Exclusionary Rule, 32 Emory Law Journal 937 (1983).

BLOTWIJK, Marc, and FERNANDEZ-BERTIER, Michael: Out-of-Court Criminal Dispute Resolution in the Netherlands, Belgium and the U.S., 2015 Tijdschrift voor Sanctierecht \& Onderneming 95 (2015). 
BOMMER, Felix, et al., Alternativ-Entwurf Abgekürzte Strafverfahren im Rechtsstaat, 166 Goltdammer's Archiv für Strafrecht (2019) 1-128.

BOYNE, Shawn: Truth or Justice: A Comparative Look at the Exclusionary Rule in Germany and the United States, in: Arnd Sinn et al. (eds.), Populismus und alternative Fakten - (Straf-)Rechtswissenschaft in der Krise?, pp. 19-46 (2020).

DALY, Yvonne Marie: Judicial Oversight of Policing: Investigations, Evidence and the Exclusionary Rule, 55 Crime, Law and Social Change 199-215 (2011).

GILLIÉRON, Gwladys: Comparing Plea Bargaining and Abbreviated Trial Procedures, in: Darryl K. Brown, Jenia I. Turner and Bettina Weißer (eds.), The Oxford Handbook of Criminal Process, pp. $703-727$ (2019). https://doi.org/10.1093/ oxfordhb/9780190659837.013.37

GLESS, Sabine, and Thomas Richter (eds.): Do Exclusionary Rules Ensure a Fair Trial? (2019).

GOLD, Russell: Beyond the Judicial Fourth Amendment: The Prosecutor's Role, 47 UC Davis Law Review 1591-1665 (2014).

KINPORTS, Kit: Culpability, Deterrence, and the Exclusionary Rule, 21 William and Mary Bill of Rights Journal 821 (2013).

ROSS, Jacqueline: The Entrenched Position of Plea Bargaining in United States Legal Practice, 54 American Journal of Comparative Law 717 (2006). https:// doi.org/10.1093/ajcl/54.suppl1.717

SLOBOGIN, Christopher: Why Liberals Should Chuck the Exclusionary Rule, 1999 University of Illinois Law Review 363 (1999).

THAMAN, Stephen C. (ed.): World Plea Bargaining (2010).

THAMAN, Stephen C. (ed.): Exclusionary Rules in Comparative Law (2013).

TURNER, Jenia I.: Plea Bargaining Across Borders (2009).

TURNER, Jenia I.: The Exclusionary Rule as a Symbol of the Rule of Law, 67 SMU Law Review 821-833 (2014).

TURNER, Jenia I.: Limits on the Search for Truth in Criminal Procedure: A Comparative View, in: Jacqueline Ross and Stephen Thaman (eds.), Comparative Criminal Procedure, pp. 280-308 (2016). 
TURNER, Jenia I., and WEIGEND, Thomas, The Purposes and Functions of Exclusionary Rules, in: Sabine Gless and Thomas Richter (eds.), Do Exclusionary Rules Ensure a Fair Trial? pp. 255-282 (2019). https://doi.org/10.1007/978-3-030-12520-2_8

TURNER, Jenia I., and WEIGEND, Thomas: Negotiated Case Dispositions in Germany, England, and the United States, in: Kai Ambos, Antony Duff, Julian Roberts and Thomas Weigend (eds.), Core Concepts in Criminal Law and Criminal Justice, vol. I, pp. 389-427 (2020). https://doi.org/10.1017/9781108649742.011

VOGEL, Mary: Plea Bargaining under the Common Law, in: Darryl K. Brown, Jenia I. Turner and Bettina Weißer (eds.), The Oxford Handbook of Criminal Process, pp. 729-760 (2019). https://doi.org/10.1093/oxfordhb/9780190659837.013.38

ZOTTOLI, Tina M., et al., State of the States: A Survey of Statutory Law, Regulations and Court Rules Pertaining to Guilty Pleas Across the United States, 37 Behavioral Sciences and the Law 388-434 (2019). https://doi.org/10.1002/bsl.2413

\section{Additional information and author's declarations (scientific integrity)}

Acknowledgement: The author is most grateful to Professor Jenia I. Turner (Southern Methodist University, Dallas TX) for her helpful remarks on a draft of this article.

Conflict of interest declaration: The author confirms that there are no conflicts of interest in conducting this research and writing this article.

Declaration of originality: The author assures that the text here published has not been previously published in any other resource and that future republication will only take place with the express indication of the reference of this original publication; he also attests that there is no third party plagiarism or self-plagiarism. 


\section{Editorial process information}

(http://www.ibraspp.com.br/revista/index.php/RBDPP/about/editorialPolicies)

- Submission date: $20 / 12 / 2020$

- Preliminary control and similarity verification: 04/01/2021

- Review 1: 08/01/2021

- Review 2: 20/01/2021

- Review 3: 24/01/2021

- Editorial decision 1: 02/02/2021

- Correction round return: $17 / 02 / 2021$

- Final editorial decision: 18/02/2021

\section{Editorial team responsible}

- Editor-in-chief: 1 (VGV)

- Associated-editor: 1 (KK)

- Reviewers: 3

\section{HOW TO CITE (ABNT BRAZIL):}

WEIGEND, Thomas. Exclusion without trial? Exclusion of evidence and abbreviated procedures. Revista Brasileira de Direito Processual Penal, Porto Alegre, vol. 7, n. 1, p. 247-271, jan./abr. 2021. https://doi.org/10.22197/rbdpp.v7i1.502

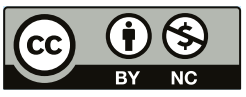

Esta obra está licenciada com uma Licença Creative Commons Atribuição-NãoComercial 4.0 Internacional. 